\title{
Crenicichla ypo (Teleostei: Cichlidae), a new species from the middle Paraná basin in Misiones, Argentina
}

\author{
Jorge Casciotta ${ }^{1}$, Adriana Almirón ${ }^{1}$, Lubomír Piálek², Sergio Gómez ${ }^{3}$ and Oldřich Ř́íčan²
}

\begin{abstract}
A new species of Crenicichla, C. ypo, is described from the Arroyo Urugua-í, a left-hand tributary of the middle Paraná River, Misiones province, Argentina. The new species is recognized by 6 to 8 irregular blotches along the upper lateral line, absence of scattered dark spots on flanks, low number (47-55) of E1 scales, and a slightly prognathous lower jaw. Females have a distinctive coloration of the dorsal fin, with a wide black longitudinal stripe on the distal portion with an equally wide red stripe below it.

Una nueva especie de Crenicichla, C. ypo, es descripta de la cuenca del arroyo Urugua-í, tributaria de la margen izquierda del río Paraná medio, provincia de Misiones, Argentina. La nueva especie es reconocida por tener 6 a 8 manchas irregulares sobre la línea lateral superior, ausencia de pequeñas manchas oscuras dispersas sobre el flanco, bajo número (47-55) de escamas en la serie E1 y la quijada inferior levemente prognata. Las hembras tienen una coloración distintiva en la aleta dorsal con una banda ancha negra en la porción distal y otra roja del mismo ancho por debajo de esta.
\end{abstract}

Key words: Water dweller, Urugua-í basin, Taxonomy.

\section{Introduction}

The genus Crenicichla Heckel includes at present about 80 valid species and is the most speciose genus within the family Cichlidae (Kullander, 2003, 2009; Casciotta et al., 2006). Most Crenicichla species are found in tropical and subtropical cis-Andean drainages (Kullander \& Lucena, 2006), although few of them, such as Crenicichla lepidota Heckel, C. vittata Heckel, and C. scottii (Eigenmann) also inhabit temperate waters in the La Plata River basin in Buenos Aires province and northern Patagonia in Argentina (Casciotta, 1987).

The Paraná River basin with 3,100,000 $\mathrm{km}^{2}$ is the second largest basin of South America, and fourteen species of Crenicichla are known from that basin (Kullander, 2003, 2009; Casciotta et al., 2006; Casciotta \& Almirón, 2008). Some of them, such as C. haroldoi Luengo \& Britski, C. jaguarensis Haseman, and C. britskii Kullander are restricted to the upper Paraná basin. Crenicichla jupiaensis Britski \& Luengo and $C$. niederleinii (Holmberg) also occur in the middle Paraná basin (Kullander, 2003; Casciotta et al., 2007), and C. mandelburgeri Kullander is endemic to the middle Paraná basin (Kullander, 1981, 2009; pers. obs.). Crenicichla iguassuensis Haseman and C. tesay Casciotta \& Almirón are restricted to the Iguazú River above the Cataratas del Iguazú (Casciotta \& Almirón, 2008). Crenicicla yaha Casciotta, Almirón \& Gómez has an interesting distribution ocurring both in the Iguazú above the Cataratas del Iguazú and in the adjacent arroyo Urugua-í (middle Paraná basin). Crenicichla semifasciata (Heckel), C. lepidota, C. scottii, and $C$. vittata are found both in the lower and middle Paraná basin (C. scottii in lower only), and the last three species also are present in the Uruguay River (Casciotta, 1987; Lucena \& Kullander, 1992).

The aim of this paper is to describe a new species of Crenicichla restricted to the arroyo Urugua-í, middle Paraná basin, Argentina.

\section{Material and Methods}

We use the following nomenclature in naming of drainages. River is used to designate large international drainages (e.g. Uruguay River), while arroyo ("stream" in Spanish) is used for smaller, exclusively Argentinean drainages (e.g. arroyo Urugua-í). This nomenclature bypasses the confusion between similar names of distinct drainages (e.g. Portuguese spelling of Uruguai for the Uruguay River vs. arroyo Urugua-í).

1División Zoología Vertebrados, Museo de La Plata, UNLP. Paseo del Bosque, 1900 La Plata, Argentina. jrcas@fcnym.unlp.edu.ar, almiron@fcnym.unlp.edu.ar

${ }^{2}$ Department of Zoology, Faculty of Science, University of South Bohemia. Branišovská 31, 37005, České Budějovice, Czech Republic. lpialek@yahoo.com, oldrichrican@yahoo.com

${ }^{3}$ Museo Argentino de Ciencias Naturales, CONICET. Av. Ángel Gallardo 470. CABA (DJR 1405), Argentina. gomezsergioe@yahoo.com 
Division of the Paraná River into sections differs substantially between various authors (e.g. Carolsfield et al., 2004; Iriondo et al., 2007). In this text we refer to the middle Paraná River as to the section from its confluence with the Paraguay River upstream to the Saltos del Guairá. Today this natural upper barrier of the middle Paraná is replaced by the Itaipu hydroelectrical dam.

Specimens were cleared and counterstained (c\&s) following the method of Taylor \& van Dyke (1985). Measurements and counts were taken as described by Kullander (1986). Pharyngeal teeth description and counts of frashed zone concavities follow Casciotta \& Arratia (1993). Holotype values are indicated by an asterisk. Body length is expressed as standard length (SL). E1 scale counts refer to the scales in the row immediately above that containing the lower lateral line (Lucena \& Kullander, 1992).

Institutional abbreviations are as listed in Ferraris (2007), except for AI (Asociación Ictiológica, La Plata, Argentina).

\section{Crenicichla ypo, new species Figs. 1-4}

Holotype. MACN-ict 9431, 105.5 mm SL, Argentina, Misiones, Paraná basin, arroyo Urugua-í, at Establecimiento “Alto Paraná”, approx. 2557.9’S 5406.5’W, Feb 1986, Gómez et al.

Paratypes. All from Argentina, Misiones, Paraná River basin. AI 212, 4, 102.0-130.0 mm SL, arroyo Falso Urugua-í, 2558'26.2”S 54¹5'28.5”W, Nov 2007, Casciotta et al. AI 263, 1 c\&s, 95.3 mm SL, arroyo Urugua-í basin, arroyo Grapia, 6 km north from Colonia Gobernador J. J. Lanusse, approx. 2552.2'S 54¹0.4'W, Nov 1986, Gómez et al. MACN-ict 9432, 3, 101.0-116.0 mm SL, arroyo Urugua-í basin, arroyo Grapia, $6 \mathrm{~km}$ north from Colonia Gobernador J. J. Lanusse, approx. 2552.2'S 54¹0.4'W, Nov 1986, Gómez et al. MACN-ict 9433, 1, 133.0 mm SL, arroyo Uruzú at route 19, Parque Provincial Islas Malvinas, approx. 2556.3’S 54¹3.0’W, Sep 1986, Gómez et al. MACN-ict 9434, 1, 111.0 mm SL, arroyo Urugua-í and route 19, Parque Provincial Islas Malvinas, approx. 2556.3'S 54¹3.0'W, Feb 1986, Gómez et al. MACN-ict 9435, 1, 137.0 mm SL, arroyo Urugua-í and route 19, Parque Provincial Islas Malvinas, approx. 2556.3'S 54¹3.0’W, Sep 1986, Gómez et al. MACN-ict 9436, 1, 123.0 mm SL, arroyo Urugua-í in Isla Palacio, approx. 2552.8'S 54²4.0'W, Feb 1986, Gómez et al. MACN-ict 9437, 1, 123.0 mm SL, same data as holotype. MACN-ict 9438, 3, 89.8-109.0 mm SL, arroyo Falso Uruguaí, 2558'26.2”'S 54¹5’28.5”W, Nov 2007, Casciotta et al.

Diagnosis. The new species is recognized in the Paraná River basin by the following combination of characters: 6 to 8 irregular blotches along the upper lateral line, absence of scattered dark spots on flanks, low number (47-55) of E1 scales, and a slightly prognathous lower jaw. Females have a distinctive coloration of the dorsal fin, with a wide black longitudinal stripe on the distal portion with an equally wide red stripe below it.

Crenicichla ypo lacks the humeral spot present in C. britskii and C. lepidota. Lateral line scales in C. ypo are without brown dots such as are present on each scale in C. haroldoi. Numerous scattered dark spots on flanks are absent in C. ypo that distinguishes this species from $C$. iguassuensis and C. tesay.
Crenicichla ypo has a distinct caudal spot, inconspicuous or absent in C. jaguarensis. Crenicichla ypo lacks the lateral stripe displayed in C. jaguarensis, C. mandelburgeri, and C. vittata.

Crenicichla ypo differs from C. jupiaensis in having lower jaw slightly prognathous, having a well-developed suborbital stripe composed of spots, and the cheek bearing up to 8 scale rows vs. isognathous jaws, a suborbital stripe reduced to a few spots posterior to the orbit, and a naked cheek.

Crenicichla ypo does not bear well developed vertical bars which are reduced to irregular blotches. This distinguishes this species from those with complete vertical bars: $C$. jupiaensis, juveniles of $C$. mandelburgeri, and $C$. niederleinii.

Crenicichla ypo differs from C. niederleinii and C. vittata in having a low number of E1 scales (47-55 vs. 56-65 and 7885, respectively).

Parallel and thin longitudinal stripes are absent in C. ypo vs. present in C. scottii.

Crenicichla ypo is easily distinguished from $C$. semifasciata in having the ascending arm of the premaxilla longer than the dentigerous one, the blotches on flanks including the upper lateral line and extending 3 to 4 scale rows above and below it, and having about half of the caudal fin scaled vs. ascending arm of the premaxilla shorter than the dentigerous one, the flanks bearing quadrangular blotches placed below the upper lateral line or lateral band, and caudal fin scaled in most of its surface.

The new species differs from C. yaha in having the lower jaw slightly prognathous and head depth $14.5-17.6 \%$ of SL vs. isognathous or upper jaw slightly prognathous and head depth 17.9-20.8\% of SL. Females of C. ypo are distinguished from females of C. yaha by having dorsal fin with a wide black stripe above a red stripe vs. dorsal fin with a wide black irregular stripe.

Description. Body elongate, depth 4.2 to 4.8 times in SL. Head as deep as wide or slightly deeper. Snout short, bluntly pointed in lateral view, 2.5 to 3.0 times in head length. Lower jaw slightly prognathous. Tip of maxilla reaching anterior margin of orbit in most specimens. Lower lip widely interrupted medially. Nostrils dorsolateral, close to anterior margin of orbit (12; MACN- ict 9431, 9432, 9434, 9435, 9437, 9438, AI 212, AI 263) or close to snout tip (5; MACN-ict 9432, 9433, 9436, AI 212). Posterior margin of preopercle serrated (12; MACN-ict 9431, 9432, 9433, 9434, 9435, 9437, 9438, AI 212, 263), or smooth on one or both sides (6; MACN-ict 9432 right side, MACN-ict 9436 both sides, MACNict 9438 left side, AI 212 right side); variation of the last two characters does not display any biogeographical pattern. Scales on flank strongly ctenoid. Head scales cycloid. Predorsal scales small, superficially embedded in skin. Prepelvic scales smaller than predorsal ones. Interopercle naked. Cheek scaled, 5 to 8 scales below eye embedded in skin. Scales in E1 row 47(2*), 48(1), 51(3), 53(5), 54(3), 55(3). Scales in transverse row 9/15(1), 10/14(1), 10/15(3), 10/16(3), 11/14(1), 11/15(6*), 11/16(2). Three scale rows between lateral lines. Upper lateral line scales 20(1), 21(2), 22(1), 23(4*), 24(1), 25(7), 27(1). Lower lateral line scales 1(1), 5(1), 9(1), 10(2), 11(6), 12(4*), 13(1), 14(1). Dorsal, anal, pectoral and pelvic fins naked. Dorsal fin XX,10(1), XXI,10(2), XXI,11(3), 


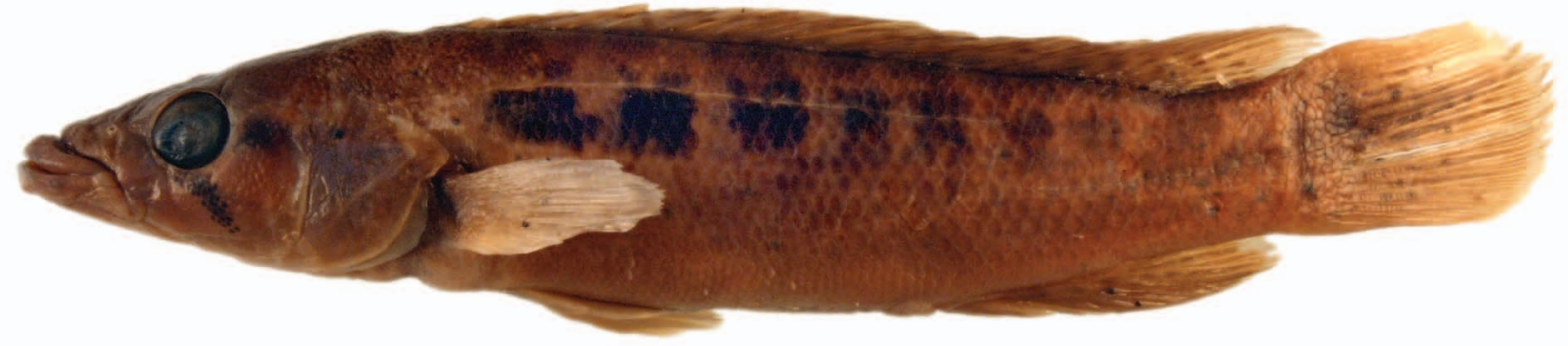

Fig. 1. Crenicichla ypo, holotype, MACN-ict 9431, 105.5 mm SL. Argentina, Misiones, arroyo Urugua-í.

XXI,12(1), XXII,10(3), XXII,11(5*), XXII,12(1). Anal fin III,7(1), III,8(13*), III,9(3). Pectoral fin 15(1), 16(16*). Caudal-fin squamation not reaching the middle of fin. Soft-dorsal fin rounded or pointed, extending beyond caudal-fin base. Tip of anal fin usually not reaching caudal-fin base (reaching in 4; MACN-ict 9431, 9432, 9433, AI 212). Caudal fin rounded. Pectoral fin rounded, reaching the tip of pelvic fin. Microbranchiospines present on second through fourth gill arches. Gill rakers externally on first gill arch: 3 on epibranchial, 1 on angle, and 8 on ceratobranchial. Two to five patches of unicuspid teeth on fourth ceratobranchial. Lower pharyngeal tooth plate with unicuspid recurved and curved crenulated bicuspid teeth, those of posterior and medial row larger than remaining ones (Fig. 4). Upper pharyngeal tooth plate with unicuspid and bicuspid teeth. Frashed zone bearing one concavity with small unicuspid teeth. Premaxillary ascending process longer than dentigerous process. Premaxilla with 20(1) unicuspid teeth on outer row, larger than inner ones. Five tooth rows near symphysis. Dentary with 25(1) unicuspid teeth on outer row, four rows near symphysis. Total vertebrae: 37 (1 c\&s). Premaxillary and dentary outer row teeth slightly movable, inner ones fully depressible.

Colour upon capture. Background colour of body grey. Deep grey preorbital stripe between anterior margin of orbit and snout tip, visible only in small specimens. Postorbital stripe between posterior margin of orbit and preopercle or opercle

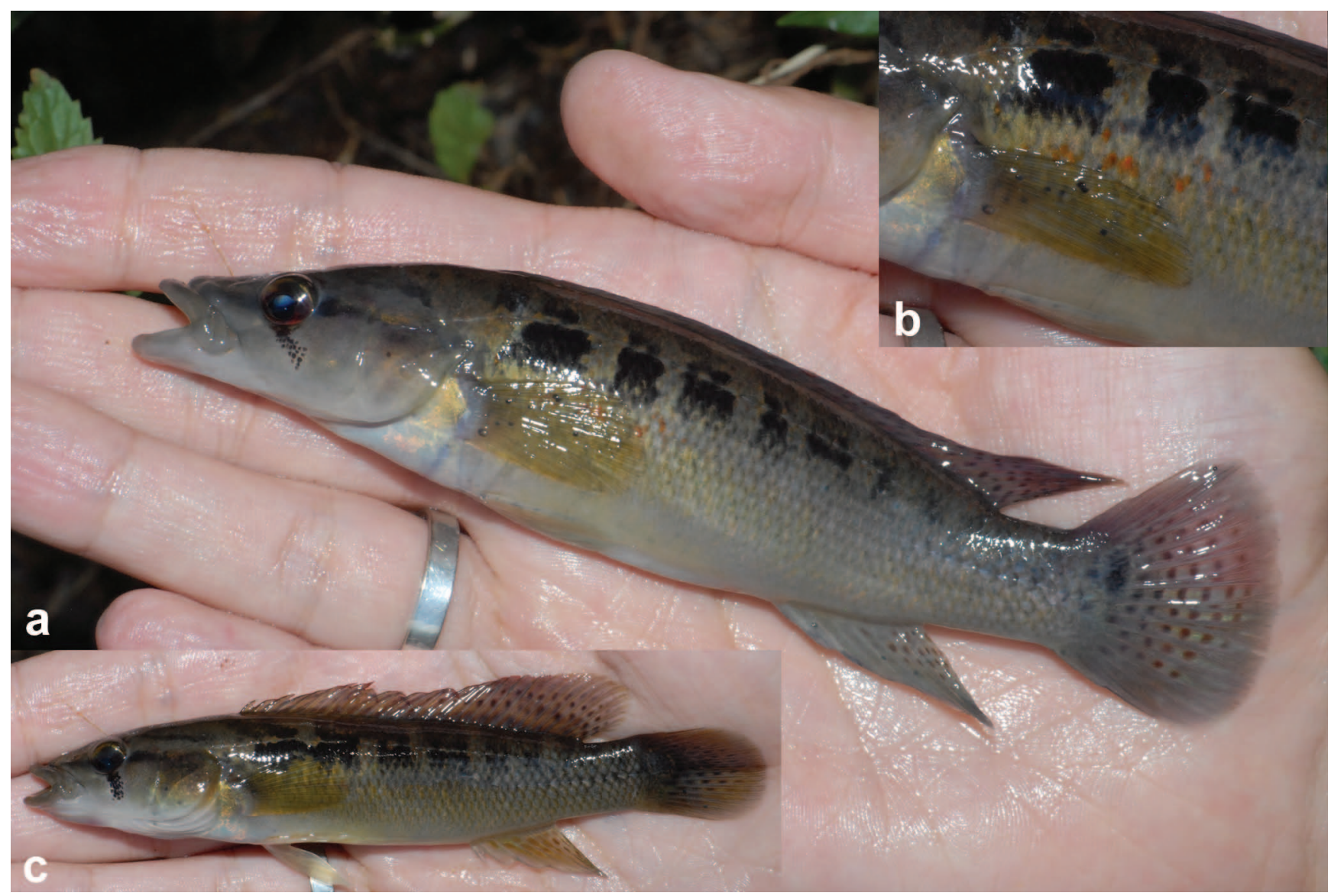

Fig. 2. Crenicichla ypo, AI 212, live male paratypes: a) $113.1 \mathrm{~mm} \mathrm{SL}$; b) detail of the orange dots on flank; and c) $102.7 \mathrm{~mm}$ SL, showing a spotted dorsal fin. 


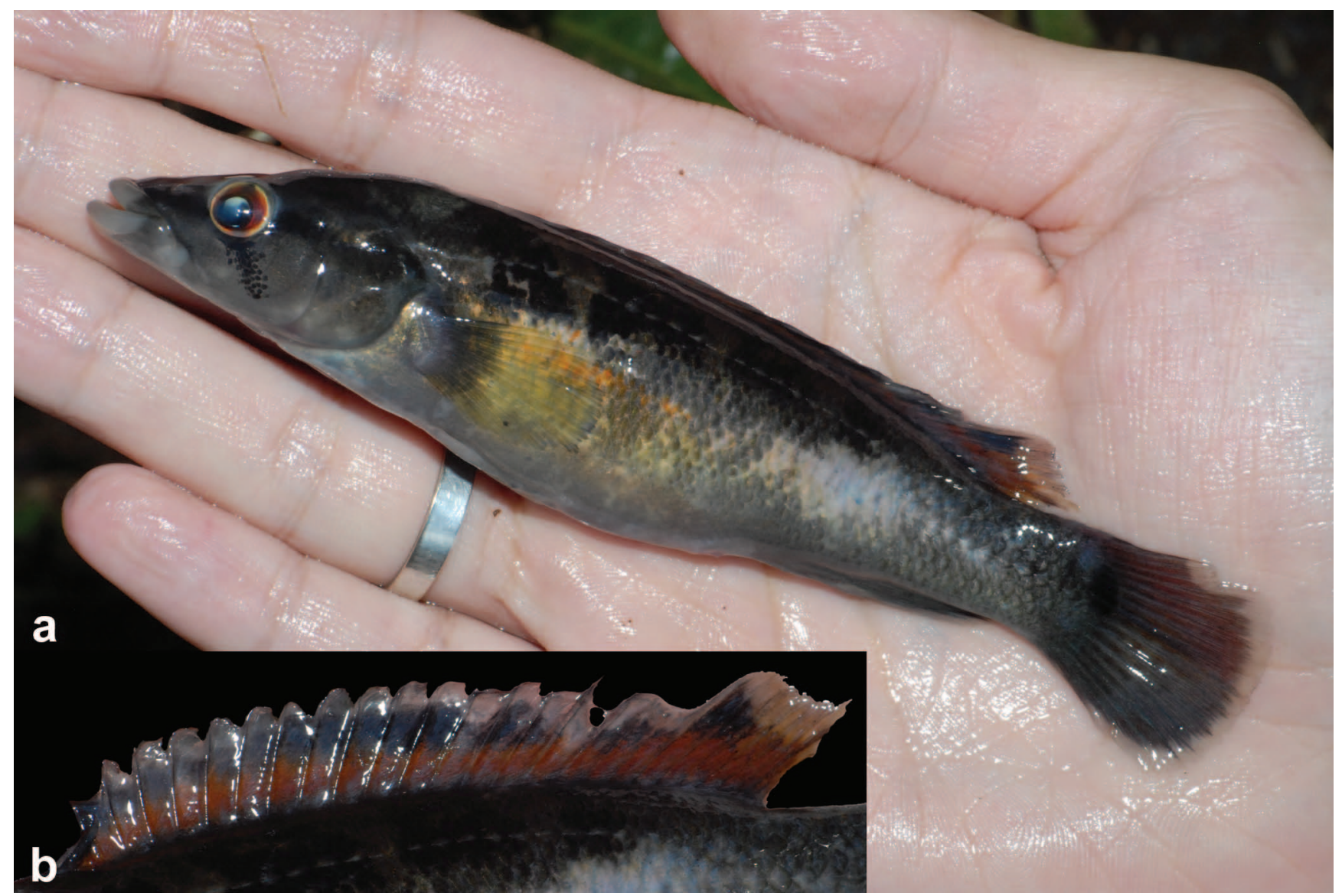

Fig. 3. Crenicichla ypo, MACN-ict $9438,104.0 \mathrm{~mm}$ SL, female, paratype: a) a freshly collected specimen damaged from gillnets; b) detail of the dorsal fin showing the diagnostic black-red stripe pattern of females.

distal margin deep grey. Suborbital stripe black almost reaching ventral margin of cheek; wide and fragmented (up to eight dots wide). Flanks with 6 to 8 irregular black blotches below (up to four scales) and above (up to three scales) upper lateral line, marginally reaching dorsal-fin base. Posteriormost blotch not extending onto caudal peduncle. Dorsal, anal, and caudal fins pale grey, males with numerous dark scattered dots on dorsal, anal, and caudal fins, (Fig. 2) which are absent or rarely seen in females. Caudal fin with a black subcircular spot, in some specimens bearing an irregular white ring, just above of midline of caudal fin. Pectoral and pelvic fins pale grey. Some male specimens with several irregular orange dots on flank at level and behind pectoral fin (Fig. 2b).

Females with head, upper half of flank, and caudal fin deep grey. Yellow and orange pigment on flank at level and behind pectoral fin. Dorsal and anal fins of females lacking small dark dots, few of them present on caudal fin. Females with a distinctive coloration of the dorsal fin, with a wide black longitudinal stripe on the distal region of dorsal fin and an equally wide red stripe below it (Fig. 3).

Colour in alcohol. Similar to that of live specimens with a tendency to become pale. Conserved specimens lack the carotenoid pigments, such as orange dots on flank of males, yellow or orange area on flank of females, and wide red stripe in dorsal fin of females.
Distribution. Crenicichla ypo is found in the arroyo Uruguaí basin, middle Paraná River basin, Misiones province, Argentina (Figs. 5-6).

Etymology. The specific epithet ypo, is a Mbya Guaraní word y po that means water dweller.

Habitat. Crenichla ypo was collected both before and after the Urugua-í hydroelectrical dam was built in 1989 (see material);

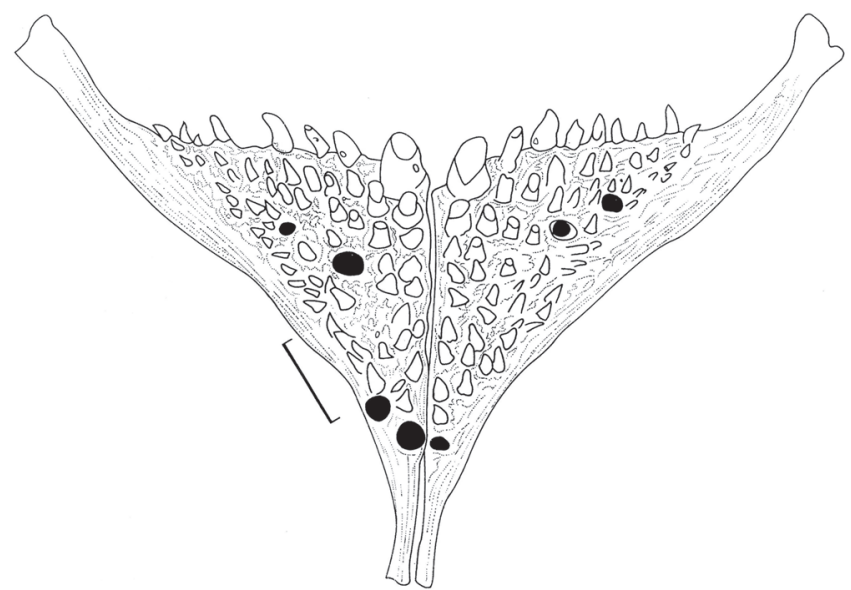

Fig. 4. Crenicichla ypo, AI 263, $95.3 \mathrm{~mm}$ SL, lower pharyngeal tooth plate in occlusal view. Scale bar $=1 \mathrm{~mm}$. 
Table 1. Proportional measurements in percents of standard length of holotype and 16 paratypes of Crenicichla ypo. SD = Standard deviation.

\begin{tabular}{lcccc}
\hline & Holotype & Range & Mean & SD \\
\hline Standard length (mm) & 105.5 & $89.8-137.0$ & - & - \\
Head length & 34.6 & $32.0-34.6$ & 33.2 & 0.76 \\
Snout length & 11.5 & $10.8-12.8$ & 11.8 & 0.64 \\
Head depth & 15.6 & $14.5-17.6$ & 16.0 & 0.97 \\
Body depth & 21.1 & $20.5-23.9$ & 22.3 & 1.05 \\
Orbital diameter & 6.6 & $5.7-7.1$ & 6.4 & 0.37 \\
Interorbital width & 6.8 & $6.2-7.9$ & 7.1 & 0.50 \\
Pectoral-fin length & 19.7 & $18.7-22.0$ & 20.1 & 0.84 \\
Caudal-peduncle depth & 12.3 & $10.9-12.9$ & 12.1 & 0.60 \\
Caudal-peduncle length & 15.4 & $14.3-16.7$ & 15.5 & 0.55 \\
\hline
\end{tabular}

the species presently occurs also directly in the reservoir (pers. obs.). The arroyo Urugua-í is a moderately fast flowing river with tributaries of an average depth of $1 \mathrm{~m}$ outside of the dam influence. Macrophytes such as Echinodorus uruguayensis Arechavaleta and Potamogeton pseudopolygonus Hagström are present. The bottom consists of mud, sand with gravel and/or bedrock. After dam construction some parts of impoundment lake are up to $6 \mathrm{~m}$ deep and some previous localities like Isla Palacio are below the water surface. Crenicichla ypo is sympatric with C. yaha and one additional undetermined Crenicichla species (pers. obs.).

\section{Discussion}

The new species, Crenicichla ypo, is in its morphology more similar to other species of Crenicichla from the Paraná River basin, than to species from the Uruguay River ( $C$. celidochilus, C. empheres, C. gaucho, C. hadrostigma, C. igara, C. jurubi, C. minuano, C. missioneira, C. prenda, C. scottii, C. tendybaguassu). These Uruguayan species are traditionally included in the C. missioneira and C. scottii species groups (Lucena \& Kullander, 1992; extended by Kullander et al., 2010), and differ from the herein discussed taxa in a combination of color-pattern and meristic characters (Lucena \& Kullander, 1992). The relationships of the new species with the Paraná River Crenicichla is also confirmed

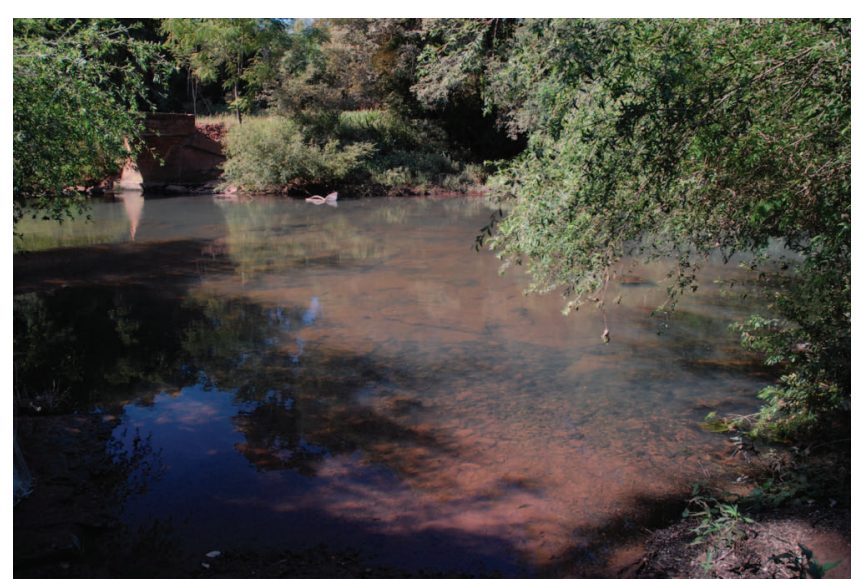

Fig. 5. Arroyo Falso Urugua-í, one of the paratype localities of Crenicichla ypo. with analysis of molecular data (mitochondrial genes ND2 and cytochrome b) which included all at-present-known species from the Misiones province (Piálek et al., in prep.). Therefore a detailed morphological comparative analysis was directed towards the Crenicichla species from the Paraná River basin.

Crenicichla ypo inhabits the arroyo Urugua-í basin, a left-hand tributary of the middle Paraná River that drains roughly 3,000 $\mathrm{km}^{2}$ of the northern part of Misiones. This river as well as most of the other tributaries of Paraná, Uruguay, and Iguazú basin in the central and northern portions of the province are divided from their main streams by a significant number of waterfalls, highest of which are invariably found closest to their mouths (pers. obs.). The isolation by high-level riverbed drops lasted apparently long enough so that many endemic taxa have evolved within these streams.

High level of endemism of the Misioneran ichthyological ecoregion (López et al., 2002; López et al., 2005) has been recently accentuated by a description of a number of endemic fish species, especially from the central and northern parts of the province, where endemism seems to be the highest (e.g. Australoheros kaaygua Casciotta et al., Iguazú; Cnesterodon pirai Aguilera et al., Cuñá-Pirú; Crenicichla tesay, Iguazú basin; Crenicichla yaha, arroyo Urugua-í and Iguazú; Hisonotus hungy Azpelicueta et al., Tirica, Paraná; Rhamdella cainguae Bockmann \& Miquelarena, Cuñá-Pirú).

Crenicichla ypo is yet another faunal element of the unique hydrography of Misiones, an hyperdiverse area lying at the intersection of three major drainages (Paraná, Uruguay, and Iguazú).

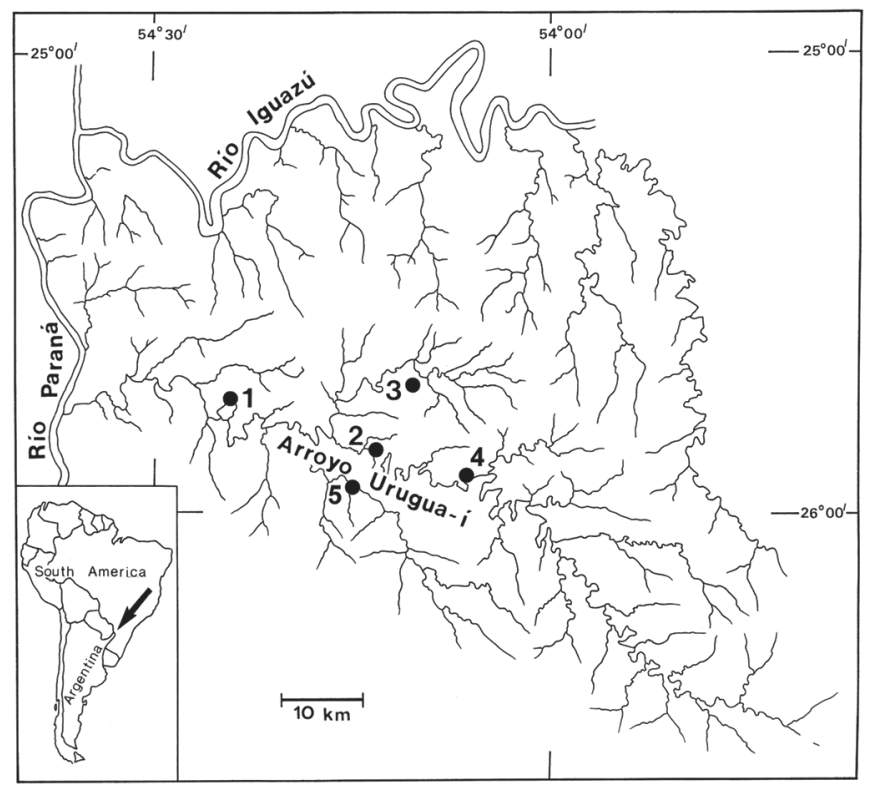

Fig. 6. Distribution of Crenicichla ypo in the Province of Misiones, Argentina. 1- Isla Palacio, 2- Parque provincial Isla Malvinas, 3-Arroyo Grapia and Arroyo Uruzú, 4- Establecimiento “Alto Paraná” (type-locality), and 5- Arroyo Falso Urugua-í. 
Comparative material. A list of comparative material of $C$. scottii and C. vittata is available in Casciotta (1987). In addition, the following material was studied: Crenicichla hadrostigma, AI 220, 1, 72.8 mm SL, Argentina, Misiones, Uruguay River basin, Itacaruare. Crenicichla iguassuensis, FMNH 54159, holotype, 137 mm SL, Brazil, rio Iguaçu, Porto União da Victoria. Crenicichla jupiaensis: Argentina, Corrientes, Paraná River at Yahapé: AI 226, 2, 87.7-93.0 mm SL; AI 227, 1, 60.7 mm SL. Crenicichla lepidota: Argentina: Buenos Aires, Isla Martín García: MACN-ict 2314, 6, 59.9-104.2 mm SL. Chaco, Esteros del Palmar: MACN-ict 7275, 1, 151.6 mm SL. Corrientes, Isla Apipé Grande, Ituzaingó: FML 312, 1, 138.0 mm SL. Entre Ríos, Uruguay River, Concepción del Uruguay: MACN-ict 4091, 1, 98.4 mm SL. Formosa, Riacho de Oro: MACN-ict 3656, 2, 116.0-165.7 mm SL. Misiones, Represa Estación Experimental Cerro Azul: MACN-ict 5067, 4, 67.7-113.4 mm SL. Salta, Luna Muerta, Hickman: FML 528, 1, 111.5 mm SL. Uruguay: Departamento Colonia, arroyo Limetas: MNHNM 2087, 1, 72.9 mm SL. Crenicichla cf. mandelburgeri: Argentina: Misiones, Paraná River basin, arroyo Chapa at route 6: MACN-ict 9442, 2, 102.2-208 mm SL. Misiones, Paraná River basin, arroyo Cuñapirú, at route 223 near Ruiz de Montoya: MACN-ict 9440, 2, 72.6-82.3 mm SL. Misiones, Paraná River basin, arroyo Cuñapirú (arroyo Tucangua): MACN-ict 9441, 7, 56.0-93.0 mm SL. Misiones, Paraná River basin, arroyo Guaruhape at route 220: MACN-ict 9439, 2, 83.7-93.0 mm SL. Crenicichla ocellata, MSNG 33700, holotype, 257.5 mm SL, Paraguay, Puerto 14 de Mayo, Bahía Negra, Chaco Boreal. Crenicichla semifasciata: Argentina: Entre Ríos, arroyo Curupí: MACN-ict 6239, 1, 176,6 mm SL. Formosa, Riacho de Oro: MACN-ict 3683, 1, 68.8 mm SL. Crenicichla tesay, MACNict 9016, holotype, $115.1 \mathrm{~mm}$ SL, Argentina, Misiones, Iguazú River basin, arroyo Verde. Crenicichla yaha: Argentina: Misiones, Iguazú River basin, arroyo Benavente: AI 199, 1, 116.6 mm SL. Misiones, Paraná River basin, arroyo Urugua-í at Isla Palacio: MACN-Ict 8924, holotype, 103.7 mm SL. Misiones, Paraná River basin, arroyo Urugua-í at provincial route 19, Parque Provincial Islas Malvinas: MTD-F 30606, paratype, 105.9 mm SL. Misiones, Paraná River basin, arroyo Urugua-í at provincial route 19, arroyo Uruzú, Parque Provincial Islas Malvinas: AI 200, paratype, 135.8 mm SL. Misiones, Paraná River basin, arroyo Urugua-í at Isla Palacio: AI 202, paratypes, 4 (1 c\&s), 37.4-48.5 mm SL.

\section{Acknowledgements}

We thank the editor and two anonymous reviewers for suggestions that improved the manuscript. We are grateful to Štepánka Hulová and Jan Štefka, both from the University of South Bohemia, for their kind help and assistance during the field expedition. Carlos Tremouilles helped us with the figures. Financial support was provided by the research project MSM6007665801 of the Czech Ministry of Education, the GACR 206/08/P003 grant (Czech Science Foundation) and a DCG grant (Deutsche Cichliden-Gesellschaft) to O. R., and Comisión de Investigaciones Científicas de la Provincia de Buenos Aires (CIC) to J.C.

\section{Literature Cited}

Carolsfield, J., B. Harvey, C. Ross \& A. Baer (Eds.). 2004. Migratory fishes of South America: Biology, Fisheries, and Conservation Status. World Fisheries Trust, IDRC/The World Bank, 380p.
Casciotta, J. R. 1987. Crenicichla celidochilus n. sp. from Uruguay and a multivariate analysis of the lacustris group (Perciformes, Cichlidae). Copeia, 1987: 883-891.

Casciotta, J. \& A. Almirón. 2008. Crenicichla tesay, a new species of cichlid (Perciformes: Labroidei) from the río Iguazú basin in Argentina. Revue suisse de Zoologie, 115: 651-659.

Casciotta, J., A. Almirón, J. Bechara, F. Ruiz Diaz, S. Sanchez \& A. González. 2007. First record of Crenicichla jupiaensis Britski \& Luengo, 1968 (Perciformes: Cichlidae) in freshwaters of Argentina. Ichthyological Contributions of Peces Criollos, 4: 1-4.

Casciotta, J. R., A. E. Almirón \& S. E. Gómez. 2006. Crenicichla yaha sp. n. (Perciformes: Labroidei: Cichlidae), a new species from the río Iguazú and arroyo Urugua-í basins, northeastern Argentina. Zoologische Abhandlungen, Staatliche Naturhistorische Sammlungen Dresden, Museum für Tierkunde, 56: 107-112.

Casciotta, J. R. \& G. Arratia. 1993. Jaws and teeth of American Cichlids (Pisces: Labroidei). Journal of Morphology, 217: 1-36.

Ferraris, C. J., Jr. 2007. Checklist of catfishes, recent and fossil (Osteichthyes: Siluriformes), and catalogue of siluriform primary types. Zootaxa, 1418: 1-300.

Iriondo, M. H., J. C. Paggi \& M. J. Parma (Eds.). 2007. The Middle Paraná River: Limnology of a Subtropical Wetland. Springer, Heidelberg, 327p.

Kullander, S. O. 1981. Cichlid fishes from the La Plata basin. part I. Collections from Paraguay in the Muséum d'Histoire naturelle de Genève. Revue suisse de Zoologie, 88: 675-692.

Kullander, S. O. 1986. Cichlid fishes of the Amazon River drainage of Peru. Stockholm, Swedish Museum of Natural History, 431p.

Kullander, S. O. 2003. Family Cichlidae. Pp. 605-654. In: Reis, R. E., S. O. Kullander \& C. J. Ferraris Jr. (Eds.). Check list of the freshwater fishes of South and Central America. Porto Alegre, Edipucrs, 729p.

Kullander, S. O. 2009. Crenicichla mandelburgeri, a new species of cichlid fish (Teleostei: Cichlidae) from the Paraná river drainage in Paraguay. Zootaxa, 2006: 41-50.

Kullander, S. O. \& C. A. S. Lucena. 2006. A review of the species of Crenicichla (Teleostei: Cichlidae) from the Atlantic coastal rivers of southeastern Brasil from Bahia to Rio Grande do Sul State, with description of three new species. Neotropical Ichthyology, 4: $127-146$.

Kullander, S. O., M. Norén, G. B. Friðriksson \& C. A. S. Lucena. 2010. Phylogenetic relationships of species of Crenicichla (Teleostei: Cichlidae) from southern South America based on the mitochondrial cytochrome b gene. Journal of Zoological Systematics \& Evolutionary Research, 48: 248-258.

López, H. L., A. M. Miquelarena \& J. Ponte Gómez. 2005. Biodiversidad y distribución de la ictiofauna mesopotámica. Pp. 311-354. In: Aceñolaza, F. G. (Ed.). Temas de la biodiversidad del litoral fluvial argentino II. INSUGEO, Miscelánea, Tucumán.

López, H. L., C. C. Morgan \& M. J. Montenegro. 2002. Ichthyological ecoregions of Argentina. Probiota: Serie Documentos $\mathrm{N}^{\circ} 1$, La Plata, Buenos Aires, Argentina.

Lucena, C. A. S. \& S. O. Kullander. 1992. The Crenicichla (Teleostei: Cichlidae) species of the Uruguai River drainage in Brazil. Ichthyological Exploration of Freshwaters, 3: 97-160.

Taylor, W. R. \& G. C. van Dyke. 1985. Revised procedures for staining and clearing small fishes and other vertebrates for bone and cartilage study. Cybium, 9(2): 107-119.

Accepted June 1, 2010 Published September 24, 2010 